\title{
UNIVERSITY WORK AS A GUARANTEE OF SUSTAINABLE DEVELOPMENT. PRACTICAL EXPERIENCES
}

María Rodríguez, Gámez, Antonio Vázquez, Pérez, Lenin Agustín Cuenca Álava

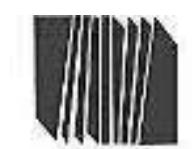

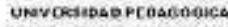
EXOLKIME MIAL LUECR TAD OH

\section{Revista}

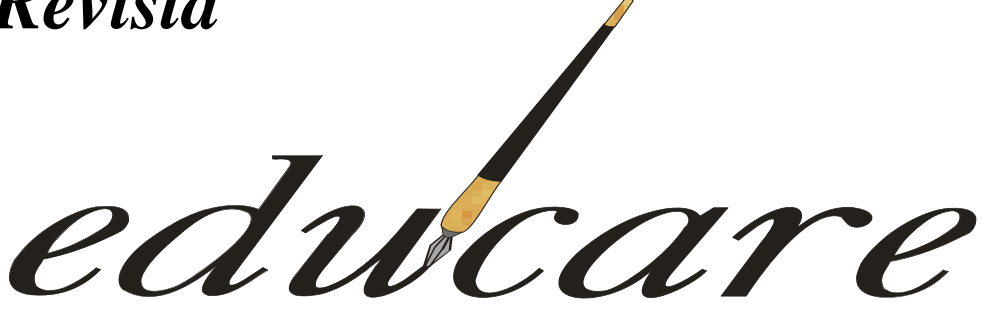

Órgano Divulgativo de la Subdirección de Investigación y Postgrado

del Instituto Pedagógico de Barquisimeto “Luis Beltrán Prieto

Figueroa”

Barquisimeto Estado Lara

Venezuela

\section{Volumen 23 № 2 Mayo-Agosto 2019}

\section{UNIVERSITY WORK AS A GUARANTEE OF SUSTAINABLE DEVELOPMENT. PRACTICAL EXPERIENCES}

LA LABOR UNIVERSITARIA COMO GARANTÍA DEL DESARROLLO SOSTENIBLE. EXPERIENCIAS PRÁCTICAS

\section{ISSN : $2244-7296$}

\author{
Autor \\ María Rodríguez Gámez \\ Antonio Vázquez Pérez \\ Lenin Agustín Cuenca Álava \\ Universidad Técnica De Manabí (UTM) \\ Ecuador
}


UNIVERSITY WORK AS A GUARANTEE OF SUSTAINABLE DEVELOPMENT. PRACTICAL EXPERIENCES

María Rodríguez Gámez, Antonio Vázquez Pérez, Lenin Agustín Cuenca Álava

(pp.56-76)

Investigación

Recibido:28-11-2018

\section{ABSTRACT}

The role that higher education can play in the interest of sustainability is an issue of international importance. The objective of the work is to create a space for reflection for the analysis of experiences related to the management of sustainability and the use of renewable energies. The deductive method was applied to address the problem from the general level, managing to interpret the actions that can be taken at the particular level. The work modality responds to a research report. The results reflect on the teaching and research experiences related to sustainability. The results of various research projects carried out within the framework of the degree work and the relationship with society, as substantive activities of the university, are presented. Finally, the conclusions show the importance of the role of the university in the interest of achieving energy sustainability.

Keywords: investigation; relationship with society; renewable sources of energy; sustainable development; teaching.

\author{
María Rodríguez Gámez * \\ Antonio Vázquez Pérez ${ }^{* *}$ \\ Lenin Agustín Cuenca Álava***
}

Aceptado: 20-05-2019

\section{RESUMEN}

El papel que puede jugar la educación superior en interés de la sostenibilidad, resulta un tema de importancia internacional. El objetivo del trabajo consiste en crear un espacio de reflexión para el análisis de experiencias relacionadas con la gestión de la sostenibilidad y el aprovechamiento de las energías renovables. Se aplicó el método deductivo para abordar la problemática desde una perspectiva general, logrando interpretar las acciones que en el plano particular se pueden adoptar. La modalidad del trabajo responde a un informe de investigación. Como resultados se reflexiona sobre las experiencias docentes e investigativas vinculadas con la sostenibilidad. Se exponen los resultados de diversos proyectos de investigación realizados en el marco de los trabajos de titulación y la vinculación con la sociedad, como actividades sustantivas de la universidad. Finalmente, en las conclusiones se expone la importancia del papel de la universidad en interés de lograr la sostenibilidad energética.

Descriptores: investigación; vinculación con la sociedad; fuentes renovables de energía; desarrollo sostenible; docencia

\footnotetext{
* Degree in Education, Physics and Astronomy, Doctor in Planning and Planning of the territory. He currently works as a research professor at the Universidad Técnica de Manabi in the career of Electrical Engineer. Email: mariarodriguez@utm.edu.ec

${ }^{* *}$ Lawyer, Master in Environmental Training. He currently works as a research professor at the Universidad Técnica de Manabí in the career of IndustryEngineer. Email: avazquez@utm.edu.ec

*** Electrical Engineer, Master in Education. He currently works as a research professor at the Universidad Técnica de Manabí in the career of Electrical Engineer. Email: icuenca@utm.edu.ec
}

Volumen 23, $N^{\circ}$ 2, Mayo-Agosto 2019. ISSN: 2244-7296 


\section{UNIVERSITY WORK AS A GUARANTEE OF SUSTAINABLE DEVELOPMENT. PRACTICAL EXPERIENCES \\ María Rodríguez, Gámez, Antonio Vázquez, Pérez, Lenin Agustín Cuenca Álava}

$($ pp.56-76)

\section{Introduction}

To a large extent sustainability depends on the proper use of natural resources, being an aspect that needs to be internalized by new generations, especially in university education.

In some cases, the issues associated with the proper use of resources, efficiency and environmental preservation are not considered transversally as specific subjects in the curricular meshes. In the best case, its content is reduced in elective subjects with no more than 64 hours in total during the entire time of the race, as is the case of the Renewable Energy Sources subject in the Electrical Engineering degree of the Technical University of Manabí in Ecuador.

It is important to consider that the university must give special attention to the importance of sustainability issues, which can be incorporated as main elements in the exercise of the substantive activities of higher education, that is, in the teaching activity, research and relationship with society (Escamez et al.2017).

The United Nations Organization (ONU), has been warning about the risks to which current society and those of future generations are subject, if there is no awareness and begin to develop strategies that help mitigate climate change, such as One of the key problems facing today's society. In 2015, the world leaders convened by the United Nations raised a set of objectives to eradicate poverty, protect the planet and ensure prosperity for all (ONU, 2015).

Sustainability education aimed at university students is the result of a process of social awareness to reduce the environmental damage associated with traditional development policies, where the consumer habit of merchandise and products, such as a spring, has been stimulated of unlimited economic growth and the satisfaction of the ever-increasing needs of society.

But it is known that the resources of nature have a limited character. Some as important as oil have begun to show the first symptoms of commercial exhaustion. In other cases, there are industrial activities that continue to have low efficiency in the use of natural resources, such as the generation of electric energy using fossil fuels, which on average only takes advantage of between $25 \%$ and $30 \%$ of the primary energy contained in the fuel.

Volumen 23, $\mathrm{N}^{\circ}$ 2, Mayo-Agosto 2019. ISSN: 2244-7296 


\section{UNIVERSITY WORK AS A GUARANTEE OF SUSTAINABLE DEVELOPMENT. PRACTICAL EXPERIENCES \\ María Rodríguez Gámez, Antonio Vázquez Pérez, Lenin Agustín Cuenca Álava}

(pp.56-76)

The other problem associated with the low efficiency in the use of natural resources, is the environmental pollution derived from the intensive use of these resources which, in the case of power generation, is considered the main source of environmental pollution (Chango, 2017).

From the above, the importance of preparing for the sustainability of university students derives, being able to contribute to the integral training of future professionals, who during the professional exercise in the labor market will have to face the important challenge of fighting against Effects of accumulated pollution in recent years and finding energy alternatives that ensure sustainable development (Molano y Herrera, 2014).

Teaching, research and the tasks of linking with society as substantive elements of the postmodern university (García y Román, 2016) contribute to the modification of values by being in contact with people in training, being able to instill values in real form, the message is more effective and controllable in terms of content and multiplier effect (Matarrita y Tuk, 2001).

Education oriented towards sustainable development through teaching processes, creates in the student a new type of awareness about the situation that confronts nature, motivated by the intensive exploitation of natural resources. It cannot be forgotten that higher education plays an important role in the social change that is required to achieve sustainability, especially in the Latin American context (Ezquerra et al. 2016).

Agenda 21 is a program that emerged at the summit of Rio de Janeiro in 1992 (ONU, 1992). In this document, guidelines are drawn up to ensure that programs and interventions are developed from the local level, based on the real knowledge of the situation of each territory, that is, that part of the local analysis as it should be expressed in the plan of action universally, Nationally and at the local level by the governments and main groups of each zone, people can positively influence the environment, a fact that students during the research process and relationship with society, can consider strategies based on the knowledge acquired on the application of actions linked to the preservation of natural resources, the elevation of efficiency and environmental protection. 


\section{UNIVERSITY WORK AS A GUARANTEE OF SUSTAINABLE DEVELOPMENT. PRACTICAL EXPERIENCES \\ María Rodríguez, Gámez, Antonio Vázquez, Pérez, Lenin Agustín Cuenca Álava}

$($ pp.56-76)

In Ecuador, specifically in the province of Manabí, the Technical University has a science faculty where future engineers are trained in the careers of Electrical Engineering, Mechanical Engineering, Civil Engineering, Chemical Engineering and Industrial Engineering. In all of them there is a close connection with the use of natural resources that are associated with gas emissions and the generation of polluting residuals.

In the Electricity Engineering degree, the Renewable Energy Sources subject is offered in two consecutive semesters, semester VII and VIII, with a duration of 32 hours respectively. Renewable energy sources are closely linked with nature, they have the potential to be repeated over time according to fixed periods and not necessarily constant volumes; that is, they are continually renewed on a regular basis and originate from the sun's energy.

In the teaching activity, the concepts associated with sustainability that relate to the subjects taught and within them the use of renewable energy sources, as well as other concepts that contribute to environmental protection and efficiency, can be incorporated in a transversal way in the use of natural resources.

\section{Materials and Methods}

Based on the experiences acquired by students during the work of linking with society, as well as the execution of research projects associated with applications of sustainable energy solutions, it is possible to demonstrate the influence on citizenship habits, related to preservation of natural resources, efficiency and energy savings.

The bibliographic review method was used that allowed to show some contributions in the field of sustainability and the efficient use of energy, assessing the levels of knowledge acquired.

The inductive method allowed to analyze the problem from the general environment, being able to particularize in the study of the subject and expose the evidences of the work. All this has allowed us to reflect on the academic experiences that make it possible to work for sustainability from the substantive activities of higher education, which reinforces the image of the formative role of the university before society.

Volumen 23, $\mathrm{N}^{\circ}$ 2, Mayo-Agosto 2019. ISSN: 2244-7296 


\section{UNIVERSITY WORK AS A GUARANTEE OF SUSTAINABLE DEVELOPMENT. PRACTICAL EXPERIENCES \\ María Rodríguez, Gámez, Antonio Vázquez, Pérez, Lenin Agustín Cuenca Álava}

$($ pp.56-76)

The work presents some results obtained through the application of qualitative techniques, such as direct and indirect observation that allowed discovering the internal relationships that take place in the problem studied, as well as the survey and interview of specialists and community actors studied in the province of Manabí, Ecuador.

\section{Analysis and Discussion of Results}

The analysis of the results is shown by exposing various projects aimed at the preservation of natural resources, increasing efficiency and environmental protection, as key elements for achieving sustainability. Among them, the experiences on the introduction of photovoltaic technology and works related to society by students are presented.

\section{Installation of a photovoltaic plant by students}

As a result of the execution of a research project and the activities of linking with society, and with the benefit of the economic support provided by the university management through the granting of 4 university scholarships to students, it was possible to design a connected photovoltaic microrred directly to the consumer's power line in distributed generation mode, with a power of $3.4 \mathrm{kWp}$.

This installation was developed between October 2015 and February 2016, accumulating 3 years and five months of uninterrupted operation, serving as a laboratory to teach students in the Electrical Engineering degree, as well as for the realization of other projects of research associated with solar energy. Figure 1 shows an image where you can see the participation of teachers and students receiving and teaching.

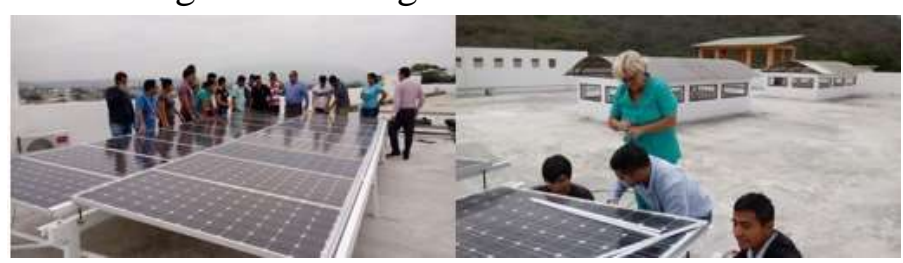

Figure 1. Participation of students and teachers in the teaching activity Source: Photos taken by the collective of authors on March 20, 2016 at the location of the photovoltaic plant installed at the Technical University of Manabí in Portoviejo. 


\section{UNIVERSITY WORK AS A GUARANTEE OF SUSTAINABLE DEVELOPMENT. PRACTICAL EXPERIENCES \\ María Rodríguez, Gámez, Antonio Vázquez, Pérez, Lenin Agustín Cuenca Álava}

$($ pp.56-76)

The photovoltaic installation was installed on the roofed surface of one of the teaching buildings of the Technical University of Manabí, allowing students to know in real time its operation, achieving in the process of linking with society to apply the acquired knowledge, being able to design new systems inside and outside the institution of higher education; in all cases as a sustainable alternative solution to the energy issue. All this gives the training process an eminently practical character that favors the creation of new knowledge through the exercise of research and the link with society.

The experiences acquired by the students then allow them to go to the communities and detect the problems that are present in the energy order, being able to make alternative proposals based on the application of renewable energy sources that favor the preservation of natural resources, at the same time that the cost of energy generated and served to final consumers is reduced, contributing to reducing greenhouse gas emissions to the atmosphere.

All this allows university students to be able to interact actively with society's problems and participate directly in their solution, contributing to the introduction of sustainable solutions that at the same time ensure economic and social development.

In the learning processes they are also trained in engineering calculations, installation quality, environmental issues and guidelines are drawn up so that what is designed or built is sustainable and lasting over time, since many of the places where they link up are remote places, which allows the promotion of independent work (Zapataet al. 2016).

As a result of the work, it was possible to apply photovoltaic technology in the university community as a measure that favors the preservation of natural resources, while reducing emissions of pollutant gases into the atmosphere. In the economic order it is possible to reduce the amount of the electric bill for energy consumption and from the social point of view the environmental image of the university before society benefits. 


\section{UNIVERSITY WORK AS A GUARANTEE OF SUSTAINABLE DEVELOPMENT. PRACTICAL EXPERIENCES \\ María Rodríguez Gámez, Antonio Vázquez Pérez, Lenin Agustín Cuenca Álava}

(pp.56-76)

\section{Linking in isolated communities}

Considering the geographical characteristics of the province of Manabí, in some cases the students carry out the activities of linking with society in isolated places and are supervised by the teachers. In the case analyzed, the link was made in the Casas Viejas rural community of the Machalilla national park. The work was carried out between the month of February 2018 until the month of July of the year 2019, totaling a time of one year and five months, where 11 visits were made to the community where the field work was carried out.

Experiences on the work of linking with society in the Electrical Engineering degree have been obtained through work in urban and rural areas. In each of them, the analyzes provided by the students are different, depending on the actual conditions they face.

This community is located forty minutes from the main road network, so that the people who live in it, have a different social situation and characteristics in relation to the use of energy systems than those residing in urban areas.

The knowledge evaluation systems acquired in classes, can be measured from the assessments that students make when working in different environments, and must link the acquired knowledge to the social conditions where they perform the linking process (García y Román, 2016). Figure 2 shows a group of students who carried out the activities of linking with society in a community that belongs to the Machalilla park, located in the Jipijapa canton.

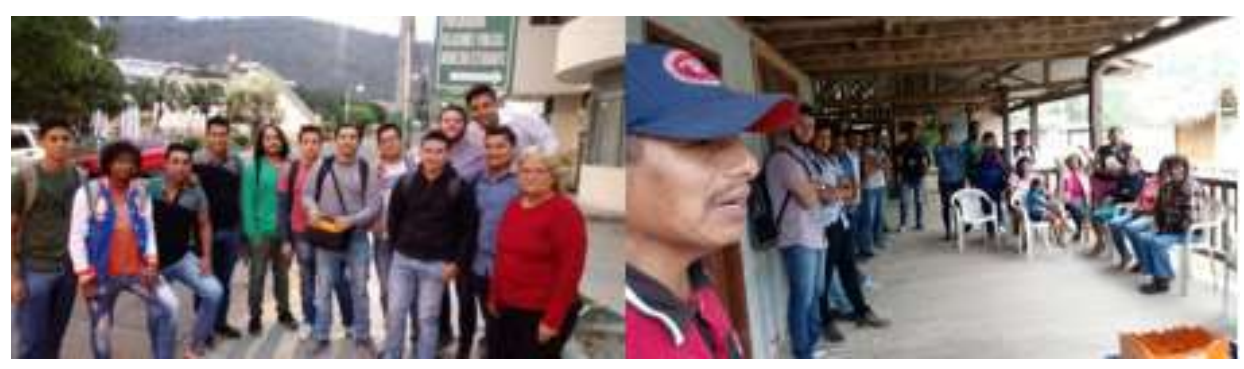

Sou Figure 2 Bonding in Machalilla Park

Source: Photos taken by the collective of authors in the Casas Viejas community, located in the Machalilla National Park, on March 12, 2019. 
UNIVERSITY WORK AS A GUARANTEE OF SUSTAINABLE DEVELOPMENT.

PRACTICAL EXPERIENCES

María Rodríguez Gámez, Antonio Vázquez, Pérez, Lenin Agustín Cuenca Álava

(pp.56-76)

\section{Synthesis of the experiences}

It can be seen that the conditions and characteristics of the photovoltaic project at the Technical University of Manabí and that related to social bonding in the Machalilla national park are different; The level of experiences acquired by students is not the same, but as a common denominator it can be seen that the training is aimed at making them capable of making comprehensive analyzes, where environmental, social and economic components are linked, according with the different scenarios in which the teaching-learning process takes place.

It can mean that in some cases during the evaluation of the process of linking with society by students, environmental and sustainability knowledge acquired by students and put into practice are not correctly assessed (Peña y Paredes, 2015). This is an element that, due to its academic importance, must be resolved with the highest priority, since the essence of the work of linking with society implies that the student takes advantage of the problems of the environment in an integral way, especially those that are related to the Environmental protection, efficiency and resource savings.

\section{Practical results measured in the Renewable Energy Sources course}

The study of the practical results achieved with the teaching of the subject of Renewable Energy Sources, in the Electrical Engineering degree of the Technical University of Manabí, was carried out considering four years of work, integrating 8 teaching semesters and taking into account the evaluation of works in the classroom of approximately 142 students who have received the subject.

During the teaching time in the subject of Renewable Energy Sources, 4 linking projects related to sustainability and renewable energy sources have been developed, two of them in the first half of the year 2019 .

When a comparison is made between the execution of projects related to society in the last two years and the previous two years, it is shown that teachers have seen the need to consider their application in the social environment, so that they contribute to the preparation of citizens

Volumen 23, $N^{\circ}$ 2, Mayo-Agosto 2019. ISSN: 2244-7296 


\section{UNIVERSITY WORK AS A GUARANTEE OF SUSTAINABLE DEVELOPMENT. PRACTICAL EXPERIENCES \\ María Rodríguez Gámez, Antonio Vázquez, Pérez, Lenin Agustín Cuenca Álava}

on issues that are related to energy sustainability. Figure 3 shows the relationship that exists in the realization of relationship projects with the company carried out in 2016 and 2017 and those that have been executed during 2018 and the first half of 2019.

Figure 3 Comparative relationship between the projects carried out in the last four years

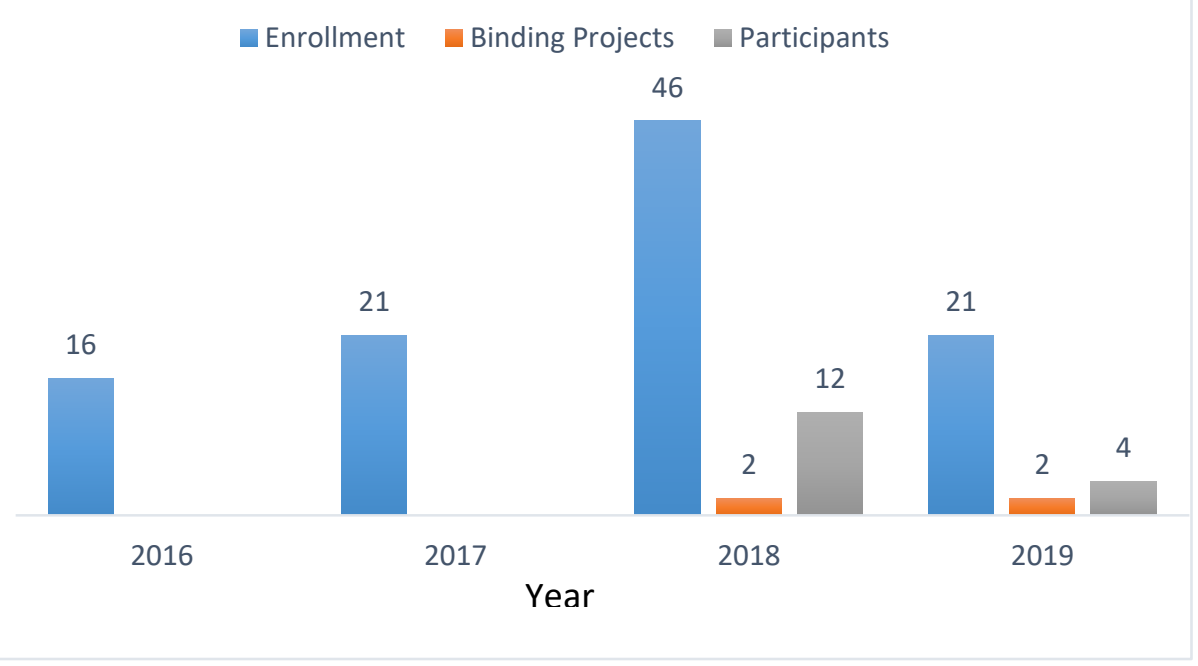

Source: self made.

In the realization of the projects, issues related to energy efficiency and the rational use of energy have been prioritized. In parallel, training has been given to the social component involved. The secondary schools have also benefited from the university's radius of action.

Despite the fact that the projects carried out are still few, their importance for the integral training of future electrical engineers can be verified, since more and more awareness of the need for their preparation is taken, while being able to provide their knowledge and experiences to the community, contributing to the formation of an ethical social behavior towards the environment.

The role of the university in social formation is essential and is becoming increasingly important, because through the activities associated with teaching, research and the relationship with society, the creation of a social ethic profiled in the protection of the environment is achieved and sustainability (Ramírezy Antero, 2014). The formation of an awareness focused on 
UNIVERSITY WORK AS A GUARANTEE OF SUSTAINABLE DEVELOPMENT.

PRACTICAL EXPERIENCES

María Rodríguez Gámez, Antonio Vázquez, Pérez, Lenin Agustín Cuenca Álava

(pp.56-76)

achieving adequate consumption habits, which break flat with the traditional consumerist doctrines linked to developmentalist policies, is encouraged to begin to understand new concepts in line with the theories of sustainability and endogenous development.

Although it is evident in Figure 3 that the projects and the participants are few, in terms of knowledge their multiplication is achieved. The linkage project started in 2018, where eight students participated, allowed to train a multilevel school located in the Casas Viejas community of the Machalilla National Park, protected area of Ecuador (Ministerio del Ambiente del Ecuador, 2007).

Within the perimeter of the Machalilla National Park there are several communities that are crossed by two rivers, in addition to the school referred to above, which does not yet have an internet connection and the information was provided by the students linked in the project, so that the linking action in that community has been satisfactory.

During the research and relationship with society, students applied the knowledge acquired in the teaching process, which made it possible to apply various research techniques such as observation, surveys and interviews with community actors, literature review and work field, among others.

Training was also provided on energy efficiency and renewable sources of energy for students of the community multilevel school, deepening issues related to the efficient use of energy, proposing appropriate methods and tools to report social benefits and guarantee efficient use of resources.

Studies were conducted on the use of water to harness the potential of the land, as well as animal husbandry. Instructional activities aimed at the community on the proper use of water in the irrigation of crops were carried out so that yields increase and productivity increases (FAO, 2014).

Measures to improve the use of water in agriculture are often understood in terms of obtaining as many crops as possible by volume of water, that is, more crops per drop of water resources. Therefore, in a broad sense, increasing productivity in agriculture can lead to greater benefits for

Volumen 23, $N^{\circ}$ 2, Mayo-Agosto 2019. ISSN: 2244-7296 


\section{UNIVERSITY WORK AS A GUARANTEE OF SUSTAINABLE DEVELOPMENT. PRACTICAL EXPERIENCES \\ María Rodríguez Gámez, Antonio Vázquez, Pérez, Lenin Agustín Cuenca Álava}

(pp.56-76)

each unit of water taken from natural water resources. However, the changes implied by the use of water in agriculture require responses from governments to ensure the productivity and sustainable use of the land and water resources on which agriculture depends.

In the Casas Viejas community of Machalilla National Park, they had for more than 15 years an American bill pump to extract water from aquifers, this device was replaced by diesel pumping, which in one way or another emits polluting gases, also in the maintenance process runs the risk of dumping waste and contaminating it, with a direct consequence for the health of the residents.

The students proposed an alternative solution based on the use of photovoltaic pumping, designing the appropriate system for the community, including training for the population and local actors, on the advantages that this system can provide to the locality.

Another of the results offered consists in the calculation and design of a photovoltaic system to supply all the energy demand for irrigation in agriculture, respecting the established environmental norms. It is estimated that the proposed system will help reduce costs for fuel purchases, in addition to eliminating greenhouse gas emissions.

The work of linking allowed to verify that in the Casas Viejas community located in the Machalilla National Park, they use the wood stove in the process of cooking food. The results of the surveys applied to the villagers showed that the biomass used corresponds mostly to remains of crops and dry branches, since being a protected area is cutting down trees.

For the community studied, the use of plant biomass from the remains of dry trees and shrubs for cooking food, which is a cheaper option than the use of liquefied gas, which would have to be moved from distant places.

It is important to emphasize that in the territory of the province of Manabí the consumption of firewood for the preparation of food in the rural sector is a constant. Considering the results of the project, the students proposed models of efficient kitchens to be used, since the population residing in the area is unaware that the rustic kitchens they are currently using cause negative effects on health and especially pregnant women.

Volumen 23, $\mathrm{N}^{\circ}$ 2, Mayo-Agosto 2019. ISSN: 2244-7296 


\section{UNIVERSITY WORK AS A GUARANTEE OF SUSTAINABLE DEVELOPMENT. PRACTICAL EXPERIENCES \\ María Rodríguez, Gámez, Antonio Vázquez Pérez, Lenin Agustín Cuenca Álava}

(pp.56-76)

The results of the surveys showed that there were people with respiratory problems in the community, probably due to inflammation of the bronchial tubes as a result of the effect of pyrolenous gases when they penetrate the respiratory system of people.

The students were able to train the residents on issues related to lung disease caused by the smoke of the culinary processes and their characteristics, posing them in addition to the most significant causes of morbidity and mortality worldwide where they occur in countries where development pathways such as Ecuador (López et al. 2014). Figure 4 shows the prototype of rustic wood-burning cuisine that is currently used in the Casas Viejas community, of the Machalilla National Park. It can be seen that it does not have a chimney to capture smoke from pyrolenous gases that can affect the health of human beings.

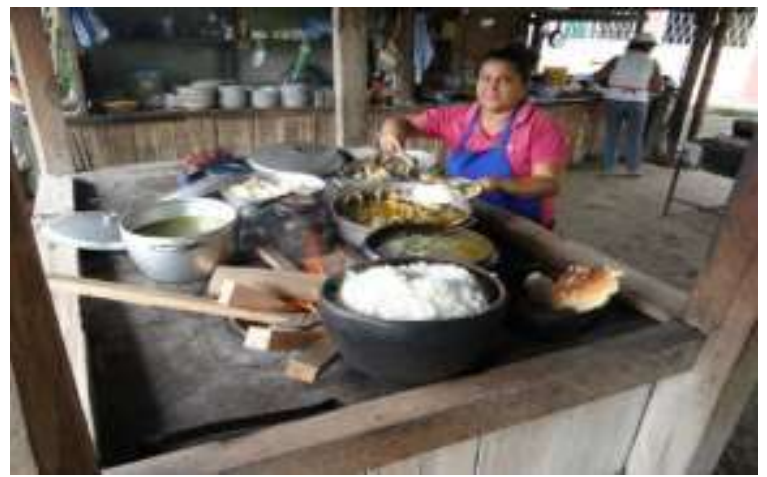

Figure 4 Rustic wood stove that is currently used for cooking food in the Casas Viejas community

Source: Photo taken by the collective of authors on March 21, 2019 in the kitchen of a rural house in the Casas Viejas community located in the Machalilla national park.

In the talks given by the students to the residents, it was stated that in other cases when the remains of dry trees and shrubs are not abundant, the consumption of firewood as fuel is not sustainable.

It was explained in the talks that, worldwide, deforestation is the main consequence of the indiscriminate consumption of plant biomass, so several countries make efforts to reduce the consumption of firewood as a source of energy. The example of Mexico was taken, which 20 


\section{UNIVERSITY WORK AS A GUARANTEE OF SUSTAINABLE DEVELOPMENT.}

PRACTICAL EXPERIENCES

María Rodríguez Gámez, Antonio Vázquez, Pérez, Lenin Agustín Cuenca Álava

(pp.56-76)

years ago made an effort with which it was achieved that $40 \%$ of the households that used firewood in 1990, were reduced to 13\% in 2000 and 7\% in 2010 (Laguneset al. 2015).

Studies in the process of linking have allowed some research, related to the amount of firewood used in Ecuador to cook food. In 2006, the demand for this type of energy was estimated, using a factor of $6.4 \mathrm{~m}^{3}$ / family / year and a number of 353,978 user families. A national consumption of 2,265,461 $\mathrm{m}^{3} /$ year was estimated. It was also determined that $75 \%$ of the firewood is used in the rural area, 10\% in the urban area, 3\% for artisanal demand, $7 \%$ for industry and 5\% for coal processing (Meza, 2001).

The inhabitants of the pre-Columbian cultures settled throughout Manabí, used wood ovens to cook their food. Nowadays the custom is maintained, it has even reached urban areas (Ramos, 2018).

It is common to find houses that have some kind of oven or wood stove for various reasons, the most common is the taste and continue with the tradition of culinary culture manaba. In Ecuador, the use of firewood in the kitchen is a practice that 48,528 people practice, according to the National Institute of Statistics and Census (Ramos, 2018).

These results have shown that students have been able to relate the knowledge acquired in teaching, research and transfer the knowledge to the community. That is why there is a need to continue influencing substantive processes such as relationship, teaching, research and relationship with society.

Other students in the realization of a project of linking with society, applied the techniques of thermography studied in classes, to demonstrate the behavior of heat (thermal radiation) and its effects on human health.

Applying thermography techniques, it was possible to obtain a group of thermal images in different conditions of use. In figure 5 (A), a person is shown using an efficient wood stove, being able to appreciate in the image that the exposure of the person who is cooking at elevated temperatures is minimal, so that the heat emissions Intense do not fully affect the body, on the contrary, the heat is concentrated in the lower cavity and is better used. In the case of figure 5

Volumen 23, $\mathrm{N}^{\circ}$ 2, Mayo-Agosto 2019. ISSN: 2244-7296 


\section{UNIVERSITY WORK AS A GUARANTEE OF SUSTAINABLE DEVELOPMENT. PRACTICAL EXPERIENCES \\ María Rodríguez, Gámez, Antonio Vázquez, Pérez, Lenin Agustín Cuenca Álava}

(B), where a rustic kitchen similar to those used in the Casas Viejas community is used, the person who is cooking is located approximately $1.2 \mathrm{~m}$, receiving a high thermal radiation, reaching temperatures in the abdominal area between 62.4 and $71.5^{\circ} \mathrm{C}$. It can be seen that the flames escape the lower cavity, which suggests that the design is not adequate, presenting a low energy efficiency.

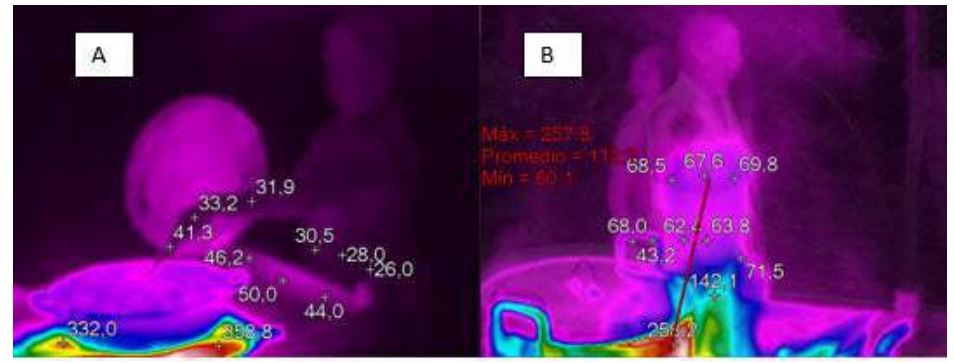

Figure 5 Emissivity of a wood stove with efficient design (A) and in (B) a low efficiency rustic

Source: Photos taken by the collective of authors on February 20, 2019 and March 21, 2019 in the Casas Viejas rural community located in the Machalilla National Park.

As a result of the research, students suggest that the surrounding air when heated and remain so during cooking time could affect not only the person who is cooking, but also those that remain relatively close to the kitchen, especially children, Elderly and pregnant women.

The results obtained during the research carried out in the Casas Viejas rural community of the Machalilla National Park, made it possible to present an analysis of the temperatures based on the distance between the hottest point of the kitchen and the person who is cooking, which allows correct the postures and the time of exposure to heat of the people who cook, in the interest of reducing health risks and achieving an adequate use of biomass as an energy resource.

\section{Responsibility and role of the university}

The results of the work of linking with the society developed by students of the Technical University of Manabí in the rural community Casas Viejas of the Machalilla National Park, demonstrates that in this process there is a social responsibility, which seen from the purely academic field, results as a cradle of ideas, projects and alternatives for the solution of social problems, requiring the contest of the potential offered by the university (Martínez et al. 2008). 


\section{UNIVERSITY WORK AS A GUARANTEE OF SUSTAINABLE DEVELOPMENT. PRACTICAL EXPERIENCES \\ María Rodríguez, Gámez, Antonio Vázquez, Pérez, Lenin Agustín Cuenca Álava}

(pp.56-76)

In the case of social responsibility, the university plays an essential role in the investigation of the policies that must be carried out and in the design of fields of action to develop strategies in search of solutions or alternatives. The university provides the social sector with data and results that are transformed into ideal complements for the development of strategies outlined in energy efficiency, the environment and community sustainability.

The vision from the Ecuadorian university (Moreira et al. 2018) lies in promoting, through the linking processes, the elements associated with sustainable development, based on the observation and application of the 2030 Agenda for Sustainable Development (ONU, 2015), which establishes the actions that Latin American and Caribbean governments must follow, aimed at achieving sustainable human development.

Considering the aforementioned, the university through the research processes that are carried out after having fulfilled the linkage, can contribute to the promotion of local development by proposing the introduction of ideas, concepts and alternative solutions to the difficulties encountered in the communities. The results of the work allow to demonstrate that the students are able to put into practice the ideas generated during the fulfillment of the substantive activities of the university.

\section{Other investigations carried out}

In the field of the Electrical Engineering degree, other investigations have also been carried out in the framework of the degree work, noting an increase from 2015 to date, confirming the interest of students in venturing into such current issues as It is sustainability linked to development at the local level (Rodriguez y Vázquez, 2015).

In 2015 by students of the Electrical Engineering degree, a degree project was presented aimed at starting an investigative process, which pursued the objective of introducing new technologies for generating clean energy at the Technical University of Manabí.

The project concluded with the introduction of a small photovoltaic technology center in building 3 of full-time professors of the Technical University of Manabí. This installation has 


\section{UNIVERSITY WORK AS A GUARANTEE OF SUSTAINABLE DEVELOPMENT.}

PRACTICAL EXPERIENCES

María Rodríguez Gámez, Antonio Vázquez Pérez, Lenin Agustín Cuenca Álava

$($ pp.56-76)

allowed to increase the possibilities of preparation of the students of the Electrical Engineering career, serving as a framework for the realization of other research projects focused on clean energy, efficiency and resource savings, reducing the cost of energy and the reduction of emissions of polluting gases into the atmosphere (Rodríguez et al. 2016).

Other research projects related to sustainability have been carried out by university students in rural areas, outlined to the increase in the quality of the electric service (Vélez, 2016), which is one of the problems to be solved in the province, Well, with the arrival of winter, the quality of energy is affected, with interruptions that usually take time to restore.

As a result of the execution of research projects on energy quality, students propose to improve it by introducing a source of clean energy generation that can complement the service of the conventional network.

With the introduction of clean energy sources in the mode of distributed generation as a complement to the conventional network, students propose to reduce losses, improve the voltage profile of the network, stabilize the frequency, decrease the cost of energy served to end users and contribute to the reduction of environmental pollution derived from the generation of electricity.

Through the execution of the projects it has been possible to deepen the study of solar potential, which in the case of the province of Manabí, presents high levels of radiation, promoting the introduction of technologies that take advantage of solar radiation throughout the territory (Saltos et al. 2016).

The experiences obtained in the degree projects carried out by the students of the Electrical Engineering degree have allowed us to deepen the study of the economic, environmental and social impacts derived from the introduction of renewable energy sources in the territory, especially installations in the mode of distributed generation.

The student can freely decide the site where he will carry out his research project-To do this, he uses the information reflected in the Geographic Information System for Sustainable Development (SIGDS) of the Technical University of Manabí, which consists of a geographic 


\section{UNIVERSITY WORK AS A GUARANTEE OF SUSTAINABLE DEVELOPMENT. PRACTICAL EXPERIENCES \\ María Rodríguez, Gámez, Antonio Vázquez, Pérez, Lenin Agustín Cuenca Álava}

$(p p .56-76)$

information system with geo referenced data of the potential of renewable energy sources and other relevant information of the social and administrative order offered by the system and that facilitate the selection of sites where it is necessary to intervene to introduce solutions based on clean energy. Figure 6 shows the relationship between the enrollment of students in the subject of Renewable Energy Sources, the research projects carried out and the participants in them, between the years 2015 to 2019 .

Enrolinent athesis a Farticipanis
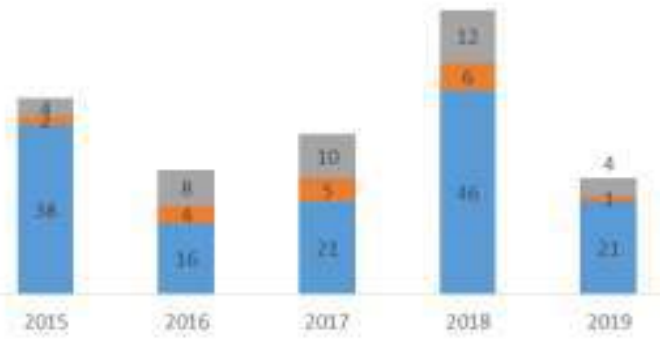

Year

Figure 6. Relationship between enrollment, research projects and participants

Source: self made.

It can be seen that the research aimed at sustainable development in the Electrical Engineering degree at the Technical University of Manabí has been increasing for years, demonstrating that students also feel committed to finding a sustainable solution to energy-related problems that society presents.

The environmental issue is of special connotation in the Electrical Engineering degree; It is recognized by different organizations and scientists, that the biggest pollution problems are linked to energy services.

Energy will continue to be a basic element for development, but despite fulfilling that role, it also produces high levels of pollution. The new generations must become aware of this problem and at the present time work to reduce its effects as part of the most urgent measures of adaptation to climate change (Laguna, 2002).

Volumen 23, $\mathrm{N}^{\circ}$ 2, Mayo-Agosto 2019. ISSN: 2244-7296 


\section{UNIVERSITY WORK AS A GUARANTEE OF SUSTAINABLE DEVELOPMENT. PRACTICAL EXPERIENCES \\ María Rodríguez Gámez, Antonio Vázquez Pérez, Lenin Agustín Cuenca Álava}

(pp.56-76)

University students have in research and links with society, the most direct ways to find sustainable solutions to the current energy problem, where although some important results are already observed and palpated, the deployment of a will is not noticeable institutional that promotes the true take off of these initiatives

\section{Conclusions}

The field in which the work is framed is to offer a reflection on the issues related to sustainability, especially related to the analysis of a group of experiences derived from teaching work, research and linking with society, as substantive activities of higher education, verifying that through its execution the transfer of knowledge and technologies to society is achieved.

Specifically, the work demonstrates the extraordinary importance of the role of the university as a driver of sustainable development, reinforcing the image and institutional prestige of higher education before society.

The literature review shows that there is varied information on the substantive activities of the university, however the role that higher education can play in the interest of sustainability is not adequately addressed, so the analysis presented in this regard constitutes a novel contribution that can be used as a starting point in other research that addresses the subject studied.

The role of academic research stands out as a mechanism par excellence generating new knowledge that, combined with the activity of linking with society, constitute an adequate way to increase the educational commitment of the university, not only of its students, but of the society in general, with a key importance to achieve the fulfillment of complex and comprehensive tasks

\section{References}

Chango, C. (2017). La contaminación ambiental y sus efectos(Tesis de Licenciatura inédita). Facultad de Comunicación y Artes Audiovisuales de la Universidad de las Américas, Ecuador. 


\section{UNIVERSITY WORK AS A GUARANTEE OF SUSTAINABLE DEVELOPMENT. PRACTICAL EXPERIENCES \\ María Rodríguez Gámez, Antonio Vázquez Pérez, Lenin Agustín Cuenca Álava}

$($ pp.56-76)

Escamez, J., Peris, J.\&Escamez, J. (2017). Educación de los estudiantes universitarios y gestión de la sostenibilidad. Perfiles Educativos, 39(156), 174-190.

Ezquerra, G., Gil, J.\& Márquez, F. (2016). Educación para el desarrollo sostenible, su dimensión ambiental: Una visión desde y para las universidades en américa. Estudios del Desarrollo Social: Cuba y América Latina, 4, 72-81.

FAO. (2014). El agua: El recurso más básico y a la vez el más indispensable.Recuperado de http://www.fao.org/zhc/detail-events/es/c/231226

García, F., \& Román, E. (2016). La vinculación con el entorno: Como proceso de enseñanzaaprendizaje. Caso universidad autónoma del estado de morelos, México. Opción, 32(11), 612-629.

Laguna, M. (2002). La generación de energía eléctrica y el ambiente. Gaceta Ecológica, 65, 5362.

Lagunes, E., Gonzáles, M. \& Ortega, A. (2015). Transición de leña a gas licuado a presión (glp) en el sur de méxico, oportunidad para la mitigación del cambio climático en la región menos desarrollada del país. Acta Universitaria, 25(6), 30-42.

López, M., Mongilardi, N.\& Checkley, W. (2014). Enfermedad pulmonar obstructiva crónica por exposición al humo de biomasa. Revista Peruana de Medicina Experimental y Salud Pública, 31(1), 94-99.

Martínez, C., Mavárez, R., Rojas, L. \& Carvallo, B. (2008). La responsabilidad social universitaria como estrategia de vinculación con su entorno social. Revista de Filosofía Jurídica, Social y Política, 15(3), 81-103.

Matarrita, R., \& Tuk, E. (2001). El papel estratégico de la educación para el desarrollo sostenible. Educación, 25(1), 19-26.

Meza, J. (2001). Estado actual de la información sobre madera para energía.Recuperado de http://www.fao.org/3/AD394S/AD394s07.htm

Ministerio del Ambiente del Ecuador. (2007). Plan Gerencial del Parque Nacional Machalilla, 2008-2010. Quito, Ecuador: Proyecto GEF: Ecuador Sistema Nacional de Áreas Protegidas (SNAP-GEF).

Molano, C., \& Herrera, J. (2014). La eucación ambiental en la educación superior. Una revisión necesaria. Revista Luna Azul, (39), 186-206.

Moreira, D., Zambrano, M.\& Muñoz, Y. (2018). Vinculación unversitaria en la interacción de actores hacia el desarrollo local ecuatoriano. Revista Didáctica y Educación, 9(2), 117126.

ONU. (1992). Programa agenda 21. Brasil: Organización de las Naciones Unidas.

Volumen 23, $N^{\circ}$ 2, Mayo-Agosto 2019. ISSN: 2244-7296 


\section{UNIVERSITY WORK AS A GUARANTEE OF SUSTAINABLE DEVELOPMENT. PRACTICAL EXPERIENCES \\ María Rodríguez, Gámez, Antonio Vázquez, Pérez, Lenin Agustín Cuenca Álava}

ONU. (2015). Objetivos de desarrollo sostenible.Santiago, Chile: CEPAL.

Peña, V. \& Paredes, S. (2015). Proyecto Plan Integrado de Vinculaión Institucional.Ecuador: Universidad Católica Santiago de Guayquil.

Ramírez, V. \& Antero, J. (2014). Evaluación de las teorias de explotación de recursos naturales: Hacia la creación de una nueva etica mundial. Revista Luna Azul, (39), 291-313.

Ramos, P. (23 de abril de 2018). El horno de barro de la campiña manabita subsiste en el tiempo. El Telégrafo, 1-2.

Rodríguez, M., Castillo, W., Vazquez, A. \& Saltos, M. (2016). Economic feasibility of extending the mains. International Scientific Research Organization Journal, 1(02), 1-9.

Rodriguez, M.\& Vázquez, A. (2015). La formación del ingeniero electricista y la sostenibilidad. Ecuador: RILCO.

Saltos, M., Rodríguez, M., Vázquez, A.\& Castro, M. (2016). Microgrids views from a geographic information system.International Research Journal of Engineering, IT \& Scientific Research, 2(11), 51-57.

Vélez, M. (2016). Photovoltaic, a choice, quality to electric service chone canton.International Journal of Science and Engineering Invention, 2(2), 1-9.

Zapata, L., Quiceno, A.\& Tabares, L. (2016). Campus universitario sustentable. Revista de Arquitextura, 18(2), 107-119. 